\title{
Study on the Enterprise Financial Management Modernization
}

\author{
Chengfeng Long \\ School of Business Administration \\ North China Electrical Power University \\ Beijing 102206, China
}

Tel: 86-10-8462-3371_E-mail: longcf2001@sina.com

\begin{abstract}
Based on defining the meanings of financial management modernization, the contents of the financial management modernization was proposed, the purpose to push the financial management modernization was further discussed, and the course gap between foreign and Chinese enterprise financial management modernization indicated that Chinese enterprise financial management modernization still should be further strengthened.
\end{abstract}

Keywords: Financial management, Modernization, Course, Gap

Up to the late of 2007, China Association of Enterprises and China Entrepreneur Association had organized 14 sessions of "Chinese National Enterprise Management Modernization Innovation Achievement", and 1211 creative achievements were evaluated. The financial management modernization is the important part of the enterprise management modernization, and Baoshan Iron \& Steel Co., Ltd, Shenzhen Airlines Co., Ltd and Zhongshan Power Supply Branch of Guang-Dian Power Grid Group had attained the great honor of "Reward of Management Modernization Result" in the financial management. But, what is financial management modernization? Which contents are concluded in the financial management modernization? Why the financial management modernization is pushed? What level is Chinese enterprise financial management modernization in comparing with western national enterprise? Aiming at these problems, a primary analysis will be made in the article.

\section{Meanings of enterprise financial management modernization}

Concretely, the enterprise financial management modernization is that the financial personnel with modern financial management concept utilize advanced financial management methods and measures to plan, organize, harmonize and control the financial activities of the enterprise, and maximize the enterprise values. The financial management modernization contains five concrete meanings. First, the financial management modernization is a special historical course and historical category in the financial management development. Second, the financial management modernization is the global concept. Third, the financial management modernization is a systematic project. Fourth, the financial management modernization possesses bright time character. With the development of the time and the advancement of the society, the degree of the financial management modernization increases continually, and the content of the financial management modernization is being enriched increasingly. Fifth, the financial management modernization presents the tendency of quick development. The course of enterprise financial management modernization in British and US has experienced for about 100 years, and the developing countries can use these successful experiences for references to more quickly realize the financial management modernization.

\section{Contents of financial management modernization}

According to the connotation of financial management modernization, the content of financial management modernization should possess two basic characters. The first character is the requirement of time, and the second character is the practical result, i.e. the financial management modernization has been tested by the practice and proved to be successful. Generally, 1970s is the period that the financial management begun mature. After 1980s, because the abundant results of natural science and social science were absorbed, especially the capital market and the market economy developed continually, the financial management begun to develop to the comprehensive management. The time of the beginning of $1980 \mathrm{~s}$ is the watershed of the time axis when the financial management is modernized. The content of financial management modernization contains following aspects.

\subsection{Modernization of financial management concept}

After 1980s, with the continual development of the market economy, especially the development of the capital market, financial management developed to the comprehensive direction, and some modern financial management concepts have been rooted in the soul of financial personnel, and these financial management concepts mainly included the financial risk concept, the coin capital time value concept and the capital cost concept. The financial management 
personnel should keep their ideas and concepts to follow the step of the time, which is the soul of the financial management modernization.

\subsection{Modernization of financial management method}

The representation form of the financial management modernization is that the financial management should actively adopt advanced modern financial management methods which have been proved effective. After 1980s, to enhance the efficiencies of decision, plan and control, and finally enhance the profit ability and competitive force of enterprise, research personnel should improve and perfect the comprehensive budget management method based on practices, and put forward $\mathrm{ABC}$ method and EVA method. These methods have been extensively applied in practice, and brought considerable economic benefit to enterprises, and they can be regarded as the modernization methods of enterprise financial management.

\subsection{Modernization of financial management measures}

Since the middle and late of 1980s, because of the spread and development of Internet and the occurrence of interactive Web application, the management mode of enterprise has spanned the limitations of time and space, and the platform to running the networking of financial management, and the networking financial management has been the modernized financial management measure recognized by the public.

\subsection{Modernization of financial management organization}

Since 1980s, many companies renamed the financial vice-president who managed financial activities in the company by the chief financial officer (CFO), and CFO has become into a management post exceeding other vice general managers in fact, and his work has been in the core position in the whole management of enterprise objectively, which is an important sign of financial management organization modernization.

\section{Purpose to push the financial management modernization}

The financial management modernization is the base and core of the enterprise management modernization. First, the modern financial management concept is the core content of the management concept modernization. Second, the modernized financial management method makes the strategy of the company to be implemented better. Third, the financial management informationization is the sign of the financial management measure modernization, and to establish the enterprise financial management information platform is one of key factors to successfully implement the enterprise management informationization.

The financial management modernization level influences the quality and efficiency of enterprise decision-making, and it can enhance the benefits of the enterprise, which has been proved in the practice. For example, after China Great Wall Aluminum Company introduced the "costing drive factor" theory of ABM, and its sales profit margin had risen from $22.24 \%$ to $40.13 \%$, and its capital yield had increased from 3.08\% to $16.06 \%$. In the year (1999) when Yunnan Copper Industry Co., Ltd implemented the budget management, its manufacturing cost and management charges all decreased to large extent. The modernization of management measures can bring multiple benefits to the enterprise. For the statistic results that US enterprises implemented the financial management informationization in recent years, the direct benefits are mainly represented in following six aspects. (1) Reducing repertory. (2) Saving 10-30\% of ground space, reducing $10-80 \%$ of machining man-hours, and decreasing $60-80 \%$ of spare part shortage rate. (3) Enhancing $5-15 \%$ of productivity. (4) The delivery rate on schedule can achieve $90-100 \%$. (5) Reducing $7-12 \%$ of costs because of the drop of repertory. (6) Increasing 10-20\% profit. And the potential advantages also include (1) enhancing decision-making level and reducing mistakes, (2) reducing the emergencies processed by managers, (3) enhancing the market change-handing ability and reflecting speed, (4) enhancing the product quality, (5) confirming the post responsibility and solving the misplacement and offside of the management layer, and realizing the effective monitor. In a word, to realize the modernization of financial management can directly or indirectly enhance the economic benefits of enterprise.

\section{Foreign and Chinese developments of financial management modernization}

\subsection{Developments of foreign enterprise financial management modernization}

After almost one century's development, the management mechanism of foreign large and middle sized companies has achieved higher level which is embodied in following aspects.

(1) Emphasizing the time value of capital and financial risk. Because most foreign enterprises are limited liability companies, so they very pay attention to the financial risk management. The first risk problem is the liability risk of the enterprise, and except for the indebted risk, the management cost of debt increases with the increase of debt, so the return of the enterprise may be decreased. On the other hand, after 1970s, foreign large-sized companies all consider the capital time value and risk return when they made investment decisions.

(2) Perfect and strict budget system. Western enterprises very emphasize the budge management, and most US 
enterprises begin to collect various materials and information in the September every year, and prepare for the financial budget of the second year. The company first proposes a primary budge in Oct to discuss in various departments, and through modifying and calculating time and again, the company will finally complete a financial budge report closing the practice.

(3) Strengthening the cost control and management. Foreign enterprises generally adopt the ABC method to control the cost. ABC method means that every activity of the enterprise is analyzed by the cost, not the cost factor, and most companies all strictly control the laborer cost. In addition, foreign enterprises very emphasize the management and control of repertory. They thought the repertory included not only the real price and freight cost (the accounting cost), but also the charge of storing repertory.

(4) Modern financial management measures. Global famous multinational companies such as General Motor, Boeing, Kodak and Sony all successfully introduced the networking financial management measures and established the informationization management platform taking the financial management as the core.

(5) Reasonable organization. CFO has been popularized in western enterprise, and it has been a management position exceeding other vice-chief general managers. The works of the financial department can be divided into two types basically. The first type work is to analyze the actuality of enterprise, explain the difference between the budge and practice, report to the administration department, and check the accounting information. The second type work is to collect accounting information, plan and utilize capitals, be responsible for financing and stock management.

Thought the historical and cultural backgrounds of developed countries such as US, Germany and Japan are difference with China, but in the situation that various large-sized companies compete to develop the international market and the competition is more and more drastic, above modernization experiences can be used for references for China from the view of financial management.

\subsection{Development of Chinese enterprise financial management modernization}

From 1949 to 1978, in the planned economic system of China, enterprises were factories in fact, and they had no right to make decisions and had no obligation to assume the failure of management form the view of financial management, enterprises needed not to financing in thus management system, because whether the concept, budget and control or the organization were executed by the government.

After reforming and opening up, the government and the enterprises first realized the importance of the financial accounting work, and adopted various measures to foster the accounting personnel with higher level. But because the enterprises even the whole society all too emphasized the financial accounting work and the importance of financial accounting, the financial accounting and the financing management were confused. This false concept largely blocked the modernization course of the enterprise financial management. After 1990s, with the development of Chinese reforming and opening up, the central status of the financial management in the enterprise management begun to be recognized gradually, and the management level was enhanced largely. Many enterprises have obtained the honors of the national enterprise management modernization innovation result in capital management, budge management, cost management, capital management, financial management information system and financing management.

\section{Gaps existing in Chinese enterprise financial management modernization}

However, comparing with western enterprises, the level of Chinese enterprise financial management modernization is still lower.

\subsection{The financial risk consciousness is deficient, and the concept of the capital time value has not been possessed.}

Qi Yinfeng and Wang Manshu's survey (2005) to 210 listed companies and 460 non-listed companies indicated that enterprises still had not sufficient financial risk consciousness. When enterprises consider the risk, they will first consider the product risk, industrial risk and technical updating risk, and the financial risk is only in the subordinate status. The listed companies, the large-sized enterprises and the enterprises with high credit class will more consider the financial risk than non-listed companies, small-sized enterprises and the enterprises with lower credit class. In the financing, the liability financial risk consciousness of state-owned enterprise is still weak. When most Chinese enterprises make decision of investment, they only consider the investment return period and the investment return rate, not the time value concept.

\subsection{Many modern financial management methods such as EVA and ABC have not been spread generally.}

Wang Yanni and Wang Anmin (2004)'s research and application of EVA just started in China, and most enterprises and investors are still not familiar with this financial originality. The survey of Nanjing University discussion group (2001) showed that $70 \%$ of Chinese enterprises adopted the batch method or the process costing method in the cost management, and the cost factors which were extensively adopted included output, direct man-hour and direct material cost. Though the standard cost accounting has been applied in $63.4 \%$ of enterprises, but only $18 \%$ enterprises modify the standard cost once every year at least, and the $\mathrm{ABC}$ and $\mathrm{ABM}$ method which are playing important roles in the enterprise sustainable competition and extensively applied by western enterprises have not be extended. 


\subsection{The modernization level of financial management measure should be further enhanced.}

For all enterprises, it is a new work to push the financial management informationization and establish a standard, high-efficient and advanced financial management information network system. Though some enterprises started early and have accumulated many experiences, but there are many concrete works to be completed.

\subsection{The financial management organization should be further optimized.}

For a long time, in the setup of Chinese enterprise management institution, only the accounting department undertaking financial accounting work equips necessary accountants. The names of these institutions includes "accounting office (department)", "finance and accounting office (department)", and "finance office (department)", but corresponding managers have not deserved rights.

Therefore, the development of Chinese enterprise financial management modernization still has quite big gap with above developed countries. To realize the financial management modernization is a systematic project, and it deals with various aspects, and relative tasks are very heavy, and the main works and main stages should be emphasized. First, the modern financial management concept must be established. Second, the modernized management method of successful enterprise should be studied and referred. Third, the financial management networking should be constructed.

\section{References}

Discussion Group of the Accounting Department of Nanjing University. (2001). Investigation and Analysis of the Cost Management Methods and Its Effects in China's Enterprises. Accounting Research. No.7.

Qi, Yinfeng \& Wang, Manshu et al. (2005). Research of Chinese Enterprise Investment and Financing Behaviors: Based on Results of Questionnaires. Management World. No.3.

Wang, Yanni \& Wang, Anmin. (2004). The Analysis of Present Applied Situation of EVA. Journal of Xidian University (Social Sciences Edition). No.14(3). 